v. $13, n .4$

Vitória-ES, Jul.-Aug. 2016

p. 72 - $93 \quad$ ISSN 1808-2386 DOI: $h$ ttp://dx.doi.org/10.15728/bbr.2016.13.4.4

\title{
An Analysis of the Determinants of Corporate Social Responsibility of Brazilian Firms
}

\author{
Vicente Lima Crisóstomo ${ }^{\dagger}$ \\ Federal University of Ceará - UFC \\ Maria Rafaela Oliveira ${ }^{\Omega}$ \\ Court of the State of Ceará - TJ CE
}

\begin{abstract}
This work makes an analysis of the determinants of Corporate Social Responsibility (CSR) of Brazilian firms, as proxied by firm membership of the ISE Index of BM\&FBOVESPA. Besides other proposed determinants of CSR present in the literature (firm size, profitability, growth opportunities), the work examines ownership concentration and the persistence on CSR status. Logit regression estimates have been run for a sample of 1649 firm-year observations in the period 2006-2011. The findings show that CSR of Brazilian firms is inversely correlated to its ownership concentration indicating that controlling voting shareholders may not see social concerns as a priority. Besides, firms tend to maintain their present CSR status. The results also indicate that leading CSR firms are larger, face more growth opportunities, and are persistent in their superior CSR situation.
\end{abstract}

Keywords: Corporate social performance. Determinants. Ownership concentration. Brazil.

t. PhD in Financial Economics by the University of Valladolid (SPAIN).

Link: Associate Professor at the Federal University of CearáUFC.

Address: Avenue of University, n. 2486, Benfica, Fortaleza CE - Brazil. Cep. 60.020-180.

E-mail:vlc@ufc.br
$\Omega$ Graduate Degree in Accounting Federal University of Ceará- UFC.

Link: Court of the State of Ceará - TJ CE.

Address: Avenue General Afonso Albuquerque Lima,

S/N, Cambeba, Fortaleza - CE - Brazil. Cep. 60822-325.

E-mail: rafitadeut@gmail.com 


\section{INTRODUCTION}

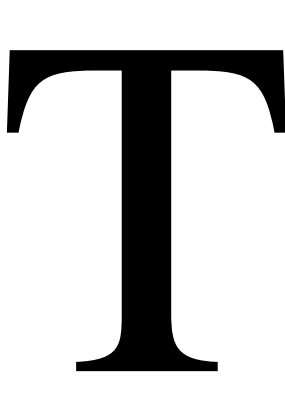

he increasing social and environmental demands have pressured firms to worry about social concerns, their operation and sustainability, being compromised with a broader range of stakeholders than the three ones articulated under the Agency Theory framework - shareholders, CEO and creditors - (JENSEN; MECKLING, 1976). Literature has highlighted that the demands of a larger spectrum of stakeholders motivate firms to worry about a sustainable approach, encompassing harmoniously, economic, social, and environmental concerns, in a way that firms, besides being profitable, become also sustainable and socially responsible (LÓPEZ; GARCIA; RODRIGUES, 2007).

An important stream of research has sought to find the motivating factors for the development of corporate social concerns at the firm level (LERNER; FRYXELL, 1988; CHIH; CHIH; CHEN, 2010; ANDRADE et al., 2013). In this context, the assessment of CSR becomes relevant. Assessing the degree of attention a firm directs to Corporate Social actions is a complex task on which there is still no agreement as can be depicted from the diversity of measures used (GRIFFIN; MAHON, 1997; MARGOLIS; WALSH, 2003; ORLITZKY; SCHMIDT; RYNES, 2003). The assessment of Corporate Social Responsibility (CSR) by specialized institutions that have created indexes of CSR that intend to be able to convey information about the level of firms' CSR has become usual (STATMAN, 2006). Examples of such market indexes are the Dow Jones Sustainability Index (DJSI) of the New York Stock Exchange, the FTSE-4Good, in the London Stock Exchange, and the Johannesburg index in South Africa. In this context, in Brazil, the Corporate Sustainability Index (ISE) of BM\&FBOVESPA has been created.

This work aims to study the determinants of CSR of Brazilian firms. To this end, we use a sample of listed Brazilian firms in the period 2006-2011, using as proxy for higher CSR the annual membership to the ISE index.

The findings have shown that ownership concentration has an adverse effect on the probability that a firm is in the ISE index. At the same time, previous status of composing the ISE index increase the probability of a firm being in the ISE today. Additionally, larger firms, firms with more growth opportunities, and more profitable firms tend to present higher probability of composing the ISE index.

Relevant literature has highlighted the need for further research looking for a sound explanation about how ownership structure moderates firm CSR in distinct institutional 
contexts (AGUILERA et al., 2007; DAM; SCHOLTENS, 2012). In this vein, this work has been developed in an specific institutional environment, an emerging economy, which has also been required (LI; ZHANG, 2010). From a theoretical perspective this research work offers additional insights on the determinants of corporate social responsibility in Brazil. The work builds on the rationale of the Agency Theory by analyzing the role played by ownership concentration on firm policies. The paper provides evidence on the negative effect of ownership concentration on CSR, proxied by the pertinence to the ISE index. As proposed by the literature, dispersed ownership concentration tends to be associated with higher public accountability, contrary to concentrated ownership, which is the picture in Latin American countries, as is the case of Brazil, where the interests of large controlling shareholders may be detrimental to firm accountability. The work also takes into account a set of other possible relevant determinants for firm social concerns. Another contribution of the work is the assessment of social performance status persistence, which is a reality in Brazil, indicating firms' concerns with reputation and legitimacy.

The remainder of the paper is organized as follows. Section 2 presents theoretical background and hypotheses. Sample and methodology are detailed in section 3. Results are analyzed in section 4 that is followed by the conclusions of the work.

\section{CORPORATE SOCIAL RESPONSIBILITY AND HYPOTHESES}

\subsection{CORPORATE SOCIAL RESPONSIBILITY}

In 1953, Howard R. Bowen, in his important book "Social Responsibilities of the Businessman", argued that society's expectations drive firm social responsibility, an idea that is still present although the need to find an adequate definition for firm social responsibility. Relevant definitions for Corporate Social Responsibility have advocated that it is related to firm concerns that are beyond the economic and market relations, but that also integrates compliance with legal requirements, ethical expectations, and respect to a broad spectrum of stakeholders and the natural environment (CARROLL, 1979; 1999; CROWTHER; ARAS, 2008).

Along with the evolution of sustainable development concerns since the 1980s, three main concepts have been pointed out as the pillars of firm social concerns (social, economic and environmental) (GARRIGA; MELÉ, 2004; DAHLSRUD, 2008). Proposed corporate social responsibility concepts allude to ethical business conduct and firm commitment to sustainable development. Indeed, the development of CSR is linked to the attempt to meet the expectations of different stakeholders, which is quite complex, since many of these 
beneficiaries may not have any relationship with the firm (SHRIVASTAVA, 1995; CARROLL, 1999; BITTENCOURT; CARRIERE, 2005; DAHLSRUD, 2008).

As previously mentioned, the growing social and environmental demands over firms has emerged the need to assess firm's social responsibility. This has given rise to a variety of measures at the firm level (LERNER; FRYXELL, 1988; STATMAN, 2006; CHIH; CHIH et al., 2010; ANDRADE; BRESSAN et al., 2013). Examples of such market indexes are the Dow Jones Sustainability Index (DJSI) of the New York Stock Exchange, the FTSE-4Good, in the London Stock Exchange, the Johannesburg index in South Africa, and the Corporate Sustainability Index (ISE) of BM\&FBOVESPA in Brazil.

\subsection{THE ISE INDEX}

Corporate Social Responsibility indexes were designed to assess firm social concerns (SKILLIUS; WENNBERG, 1998; STATMAN, 2006). Following an international trend, in 2005, the Brazilian market has created an index with the aim to assess CSR of Brazilian firms, the Corporate Sustainability Index (ISE). ISE was established by BM\&FBOVESPA, being the first index of the kind in Latin America (MARCONDES; BACARJI, 2010). ISE is proposed to be an index that assess firm's concerns about the three pillars of sustainability (social, economic and environmental).

\subsubsection{The ISE methodology and questionnaire}

ISE is a theoretical portfolio, selected among the most traded firms in the Brazilian stock exchange market, and better graded in terms of CSR in the year, through an assessment process conducted by the ISE Executive Council. A set of required criteria must be fulfilled for a firm that intends to participate in the process (BM\&FBOVESPA, 2012): (i) be one of the 200 stocks with highest market trading in the previous year, (ii) have been traded in at least $50 \%$ of the stock exchange sessions in the previous year, (iii) comply with the sustainability criteria endorsed by the ISE Executive Council.

ISE Executive Council has adopted the concept of sustainability focused on the three axes of the Triple Bottom Line (TBL) (GARRIGA; MELÉ, 2004; DAHLSRUD, 2008; BM\&FBOVESPA, 2012), featuring a sustainable business management as one that integrates adequately the social, economic and environmental dimensions of business. The ISE Executive Council has contracted the Center for Sustainability Studies of the Getúlio Vargas Foundation for the preparation of firm annual review. That is done through a questionnaire that the firm responds in a voluntary manner. 
Firm assessment is based on a quantitative analysis that takes into account the questionnaire score, in which all dimensions have the same weight, with specific multiplechoice questions. Additionally, there is also a qualitative analysis based on the verification of supporting documents that are requested at the end of the enquiry period. After the questionnaire analysis, cluster analysis is run in order to identify groups of firms with similar CSR, and make up firm ranking to compose the ISE portfolio with up to 40 best performing firms (BM\&FBOVESPA, 2012).

\subsection{HYPOTHESES RATIONALE}

A set of factors have been examined as able to affect the propensity of the firm to improve Corporate Social Responsibility (CSR). Literature has considered, under distinct theoretical frameworks, some firm characteristics as able to affect CSR. Among such factors are profitability, size and leverage, for example. More recently, aspects of ownership structure and growth opportunities have also been considered.

\subsubsection{Ownership concentration and CSR}

Agency conflicts among key stakeholders, such as shareholders, managers and creditors, treated by the Theory of the Firm (JENSEN; MECKLING, 1976), are moderated by ownership structure as the evidence has shown. For instance, conflicts between owners and managers are typical in markets with low ownership concentration, in contrast to other conflicts related to concentrated ownership, in which divergent interests between major and minority shareholders seem to be more relevant (CUERVO, 2002; CLAESSENS; YURTOGLU, 2013). Besides, evidence has also been found that different aspects of ownership structure affect firm value and performance (ALLEN; PHILLIPS, 2000; VILLALONGA; AMIT, 2006), as well as investment and financing policies (SCHIANTARELLI; SEMBENELLI， 2000; GOERGEN; RENNEBOOG， 2001; CRISÓSTOMO, 2011). Facing such evidence, it is feasible to propose that ownership structure may also moderate firm CSR, since certain shareholders may be more interested in improving CSR.

Initial research has documented the effect of ownership structure on CSR policy with inconclusive results (ROBERTSON, 2009; BARNEA; RUBIN, 2010; LI; ZHANG, 2010; GODOS-DÍEZ; FERNÁNDEZ-GAGO; CABEZA-GARCÍA, 2012). Some studies have found a positive effect of ownership concentration on CSR with some nuances. In Spain, a positive effect of ownership concentration in hands of the main shareholder has been detected (GODOS-DÍEZ; FERNÁNDEZ-GAGO et al., 2012). In Singapore and Malaysia, a positive 
effect of ownership concentration held by the government has been documented (ENG; MAK, 2003; SAID; ZAINUDDIN; HARON, 2009). Ownership of institutional investors has been found to be positively related to CSR in USA (JOHNSON; GREENING, 1999; HARJOTO; JO, 2008). On the other hand, CSR is negatively affected by internal ownership in USA (BARNEA; RUBIN, 2010), or by ownership concentration in hands of the main shareholder in the European scenario (LÓPEZ-ITURRIAGA; LÓPEZ-DE-FORONDA, 2011), and also in non state Chinese firms (LI; ZHANG, 2010).

High ownership concentration, usually associated to a reduced number of controlling shareholders, favors the reduction of agency conflicts between managers and owners by facilitating management monitoring and alleviating the free-rider problem. On the other hand, it may also allow the exacerbation of private benefits of control in different ways (DYCK; ZINGALES, 2004; RIYANTO; TOOLSEMA, 2008). This excess power may be detrimental to the improvement of CSR if controlling shareholders do not see social policy as relevant for firm value creation. Taking into account the previous results on the inconclusiveness about the value creation capacity of social policy (GRIFFIN; MAHON, 1997; MARGOLIS; WALSH, 2003; ORLITZKY; SCHMIDT et al., 2003), the negative effect of CSR on firm value documented in Brazil (CRISÓSTOMO; FREIRE; VASCONCELLOS, 2011), and the negative effect of ownership concentration on the probability of the firm compose the ISE index (NUNES et al., 2010; LOURENÇO; CASTELO BRANCO, 2013), we propose the hypothesis that controlling shareholders in high concentrated ownership Brazilian firms are not prioritizing social policy, in the following terms:

Hypothesis 1: Ownership concentration is adversely related to firm CSR in the Brazilian market. This leads to the expectation that higher ownership concentrated firms are less likely to compose the ISE portfolio.

\subsubsection{Persistence on CSR}

The importance given to social responsibility suggests that firms are aware of the importance of firm social policy, as a consequence of the expanding social and environmental demands over firms. Firm legitimacy, a kind of "social contract" between firm and society, is associated to proper and desirable actions of a firm within a social system (DEEPHOUSE; CARTER, 2005). Building on the Legitimacy Theory that proposes that firms try to legitimize their actions (DEEGAN, 2002; TILLING; TILT, 2010), it is plausible to propose that firm may use CSR for that. Regardless the reasons for disclosing CSR, the purpose to legitimize firms' activities is to gain legitimacy with relevant stakeholders (DOWLING; PFEFFER, 
1975; SUCHMAN, 1995; DEEGAN, 2002). By undertaking CSR policy and disclosing it, directly or being evaluated externally and composing CSR indexes (STATMAN, 2006; ANDRADE; BRESSAN et al., 2013), the firm signals its concern with CSR to the market and society as a whole. The way back in this process may be a negative signal with adverse consequences on the firm legitimacy process. By adopting certain social actions and reaching a certain degree of CSR, it is plausible to propose that a firm will try to increase, or, at least, maintain its present CSR, in a way to show to different stakeholders that the firm is actually committed to such concerns. This rationale leads to a hypothesis proposal that firms try to keep their CSR status, as follows:

Hypothesis 2: Firms worry on keeping their present degree of CSR. This leads to the expectation that present membership to the ISE portfolio is positively affected by the previous pertinence to the index.

\subsubsection{Growth opportunities and CSR}

Firm's Growth opportunities have been seen as capable to moderate the intensity of social actions. The need to seize growth opportunities requires firm capacity to raise external funds for investment. Raising funds for firm financing requires the firm to be committed with social and sustainability standards, which is increasingly important in the funding market. Literature on corporate social responsibility has highlighted such relevance and the positive sensitivity between growth opportunities and CSR (ARTIACH et al., 2010; LOURENÇO; CASTELO BRANCO, 2013). This line of reasoning suggests that the firm with growth opportunities may be more prone to look for high CSR standards in order to be well regarded by the funding market as proposed in the following hypothesis:

Hypothesis 3: Growth opportunities contribute positively to firm social concerns. This leads to the expectation that firms with more growth opportunities are more likely to compose the ISE portfolio.

\subsubsection{Profitability and CSR}

Stakeholder theorists argue that concern with a broad spectrum of stakeholders does not exclude the trio shareholder-manager-creditor (FREEMAN; PHILLIPS, 2002; FREEMAN; WICKS; PARMAR, 2004). However, under this broader perspective, business activity must take into account maximizing not only shareholders interests but also other stakeholders interests, undertaking CSR actions. Thus, the firm vision is expanded by integrating an ethical and responsible conduct in its dealing with various stakeholders. 
Waddock (2004) argues that there is no reason for the existence of conflict between a profitable company and the respect for firm stakeholders and society as a whole. The Stakeholder Theory proposes the virtuous cycle between CSR and firm performance, under the rationale that CSR actions are able to create value for the firm since society has a positive sensitivity to this type of corporate action (FREEMAN; WICKS et al., 2004). The complement of the virtuous cycle is related to the slack resource Theory. Under the slack resource theoretical framework, better financial performance leads to higher availability of not only financial but also other slack resources that empower the firm to undertake social policy, be it related to employee relations, community relations, or environmental and sustainability concerns. Under such rationale, better financial performance, usually associated to the availability of slack resources, would be a determinant of better corporate social concerns (WADDOCK; GRAVES, 1997; HUSTED; SALAZAR, 2006; BARON; HARJOTO; JO, 2011). Following this argument, we consider appropriate hypothesizing that higher profitability contributes to higher CSR.

Hypothesis 4: Profitability contributes positively to CSR of the Brazilian firms. This leads to the expectation that firms with higher profitability are more likely to compose the ISE portfolio.

\subsubsection{Firm size and CSR}

Despite arguments about the possible effect of firm size on CSR are still controversial (ORLITZKY, 2001; UDAYASANKAR, 2008; BAUMANN-PAULY et al., 2013), firm size has been an important control variable in research on determinants of CSR. The argument about the positive effect of firm size on CSR posits that larger firms have more capacity to provide infrastructure and financial resources to undertake social policy. Besides, as the firm grows it becomes more visible and interacts with a broader spectrum of stakeholders experiencing greater demand for firm social responsibility, leading to higher level of mutual interference between business and society. In this sense, firm size seems to become more relevant for CSR. Bigger firms tend to be charged for shareholders and society at large so that they are more compelled to integrate social concerns and ethical conduct (ULLMAN, 1985; ORLITZKY, 2001; ARTIACH; LEE et al., 2010; ZIEGLER; SCHRÖDER, 2010; ANDRADE; BRESSAN et al., 2013; LOURENÇO; CASTELO BRANCO, 2013). In this regard we propose the hypothesis that larger firms will be more prone to undertake social policy, leading to better CSR, as summarized in the following hypothesis that predicts a positive effect of firm size on CSR: 
Hypothesis 5: Firm size affects positively firm CSR. This way, it is expected that larger firms are more likely to compose the ISE portfolio.

\section{METHOD AND SAMPLE}

\subsection{METHOD}

Literature has commented the difficulties in measuring CSR, which may arise due the diversity of CSR actions a firm may undertake as well as the voluntary aspect of its disclosure, and even the still uncertain CSR definition (WADDOCK; GRAVES, 1997; AGUINIS; GLAVAS, 2012). Corporate Social Responsibility (CSR) indexes are subject to complex measuring strategies as can be seen in the variety of indexes used (LI; TANG, 2007; HODGSON; LHAOPADCHAN; BUAKES, 2011).

Using the membership to the ISE index as proxy for the level of firm CSR we estimate logit models in which the dummy variable ISE is the dependent variable as can be seen in model of equation (1):

$$
I S E_{i, t}=\beta_{0}+\left[\beta_{1 .} I S E_{i, t-1}\right]+\beta_{2 .} O W C+\beta_{3 .} R O A_{i, t}+\beta_{4 . G R O P}{ }_{i, t}+\beta_{5 .} S I Z E_{i, t}+\varepsilon_{i, t}(1) .
$$

In this model, the dummy variable ISE is set to 1 if the firm-year observation is present in the ISE index, and 0 otherwise. The lagged presence in the ISE index ( ISE $\left._{i, t-1}\right)$ is included in an alternate model of equation (1) in order to evaluate the possible persistence of the firm composing the ISE index.

OWC stands for ownership concentration. This variable has been measured as voting ownership concentration in hands of the main owner, the sum of ownership concentration in hands of the two main owners, and so forth until the sum of voting shares owned by the five main stockholders. Besides, for robustness of results, ownership concentration is also measured by the annual Herfindahl index for each firm-year observation, corresponding to the sum of squares of stocks held by each of the five main shareholders as done in previous works (MAURY; PAJUSTE, 2005; CRISÓSTOMO; LÓPEZ-ITURRIAGA; VALLELADO, 2014). Profitability has been proxied by ROA (Return on Assets). Growth Opportunities (GROP) have been proxied by Tobin's $\boldsymbol{q}$ and calculated as the ratio between firm market value plus debt, and firm accounting value, as usual in the literature (VILLALONGA; AMIT, 2006). Finally, firm size (SIZE) has been proxied by $L n$ of firm total assets.

Besides these multivariate estimates we also perform univariate tests for firm financial characteristics to compare ISE firms, considered leading CSSP firms, and conventional firms, 
i.e., non ISE firms. Such tests allow us to have an idea about the differences between the two groups of firms.

\subsection{SAMPLE}

This work has used a sample composed of 1,649 firm-year observations in the period 2006-2011. Financial and ownership data have been collected from Economatica database while the fact of composing the annual ISE index has been verified at BM\&FBOVESPA records. The sample is well distributed among several important sectors of the economy as can be seen in Table 1 .

Table 1- Sample Distribution by Industry

\begin{tabular}{|c|c|c|c|c|c|c|}
\hline & Full sample & & $\begin{array}{r}\text { ISE } \\
\text { firms }\end{array}$ & & $\begin{array}{r}\text { on ISE } \\
\text { firms }\end{array}$ & \\
\hline Industry & $\mathrm{n}$ & $\%$ & $\mathrm{n}$ & $\%$ & $\mathrm{n}$ & $\%$ \\
\hline Petroleum and fuel products & 29 & 1.76 & 2 & 1.12 & 27 & 1.84 \\
\hline $\begin{array}{l}\text { Chemicals, Paper products, Metal- } \\
\text { mechanical }\end{array}$ & 252 & 15.28 & 32 & 17.88 & 220 & 14.97 \\
\hline $\begin{array}{l}\text { Equipment, Electrical machinery, and } \\
\text { transport equipment }\end{array}$ & 130 & 7.88 & 13 & 7.26 & 117 & 7.96 \\
\hline Building and transportation & 186 & 11.28 & 10 & 5.59 & 176 & 11.97 \\
\hline Food products and beverages and tobacco & 156 & 9.46 & 10 & 5.59 & 146 & 9.93 \\
\hline Textile, clothing, leather and footwear & 197 & 11.95 & 6 & 3.35 & 191 & 12.99 \\
\hline Communication & 65 & 3.94 & 7 & 3.91 & 58 & 3.95 \\
\hline $\begin{array}{l}\text { Electrical, Water supply and sanitary } \\
\text { services }\end{array}$ & 232 & 14.07 & 65 & 36.31 & 167 & 11.36 \\
\hline Financial & 171 & 10.37 & 24 & 13.41 & 147 & 10.00 \\
\hline Others & 231 & 14.01 & 10 & 5.59 & 221 & 15.03 \\
\hline Total & 1,649 & 100 & 179 & 100 & 1,470 & 100 \\
\hline
\end{tabular}

\section{RESULTS}

Table 2 shows descriptive statistics of model variables. Our findings on ownership concentration agree with previous works in Brazil showing that, in fact, Brazilian firms face high ownership concentration (LA PORTA et al., 1998; LÓPEZ-ITURRIAGA; CRISÓSTOMO, 2010; SILVEIRA et al., 2010). The average ownership concentration of voting shares is around 55\% in hands of the main shareholder (OWC1) and reaches $77.57 \%$ in hands of the five main voting shareholders (OWC5). Such characteristic of high ownership concentration may lead to specific effects on certain firm strategic policies as previously found, and possibly also on CSR policy. Brazilian firms have an average ROA of $8.1 \%$. 
Table 2- Descriptive Statistics for Sample Variables

\begin{tabular}{lrrrrrrr}
\hline \multicolumn{1}{c}{ variable } & $\mathrm{N}$ & mean & $\mathrm{sd}$ & $\mathrm{cv}$ & median & $\min$ & $\max$ \\
\hline HI5 & 1649 & 0.4161 & 0.2980 & 0.7161 & 0.3531 & $1.96 \mathrm{e}-06$ & 1.0000 \\
OWC1 & 1649 & 0.5509 & 0.2713 & 0.4925 & 0.5388 & 0.0014 & 1.0000 \\
OWC2 & 1649 & 0.6799 & 0.2492 & 0.3665 & 0.6996 & 0.0014 & 1.0000 \\
OWC3 & 1649 & 0.7334 & 0.2287 & 0.3119 & 0.7673 & 0.0014 & 1.0000 \\
OWC4 & 1649 & 0.7611 & 0.2147 & 0.2822 & 0.8089 & 0.0014 & 1.0000 \\
OWC5 & 1649 & 0.7757 & 0.2069 & 0.2667 & 0.8272 & 0.0014 & 1.0000 \\
ROA & 1649 & 0.0811 & 0.1093 & 1.3482 & 0.0661 & -0.1478 & 0.3291 \\
GROP & 1649 & 1.2830 & 1.1359 & 0.8853 & 0.9612 & 0.0087 & 6.2200 \\
SIZE & 1649 & 13.6153 & 1.7408 & 0.1279 & 13.5492 & 8.9965 & 19.9781 \\
\hline
\end{tabular}

Notes:

HI5 is the Herfindahl index for voting ownership concentration in hands of the five main shareholders. OWC (1 to 5) refers to the sum of voting shares (\%) in hands of the main, the two main, and so forth, until the five main shareholders. ROA is return on assets. GROP stands for growth opportunities, proxied by Tobin's Q. SIZE proxies for firm size, being calculated as Ln of total assets.

Advancing in the descriptive analysis it is worth mentioning that ISE and Non ISE firms are, indeed, different as can be seen in Table 3 which contains mean comparison tests for model variables. As can be observed, ISE firms present inferior ownership concentration (OWC), more growth opportunities (GROP), and profitability (ROA). Mean test have been computed by parametric and non parametric tests for robustness of results.

Table 3 - Comparing ISE versus non ISE Firms

\begin{tabular}{lrrrr}
\hline & ISE firms & non ISE firms & $\mathrm{t}$ test & non parametric test \\
\hline Variable & mean & mean & p-value & p-value \\
\hline OWC1 & 0.5102 & 0.5559 & 0.0167 & 0.0224 \\
OWC2 & 0.6596 & 0.6824 & 0.1246 & 0.0798 \\
OWC3 & 0.7096 & 0.7363 & 0.0701 & 0.0185 \\
OWC4 & 0.7366 & 0.7640 & 0.0535 & 0.0060 \\
OWC5 & 0.7494 & 0.7789 & 0.0355 & 0.0021 \\
HI5 & 0.3656 & 0.4223 & 0.0081 & 0.0378 \\
ROA & 0.1214 & 0.0761 & 0.0000 & 0.0001 \\
GROP & 1.5714 & 1.2479 & 0.0002 & 0.0027 \\
SIZE & 15.6513 & 13.3673 & 0.0000 & 0.0001 \\
\hline NOtes: & & & &
\end{tabular}

Notes:
HI5 is the Herfindahl index for voting ownership concentration in hands of the
five main shareholders. OWC ( 1 to 5$)$ refers to the sum of voting shares (\%) in
hands of the main, the two main, and so forth, until the five main shareholders.
ROA is return on assets. GROP stands for growth opportunities, proxied by
Tobin's Q. SIZE proxies for firm size, being calculated as Ln of total assets. Non
parametric test is Mann-Whitney.

Table 4 exhibits correlation coefficients for variable models. As can be seen, there is a trend for a negative correlation between the probability of composing the ISE index and ownership concentration. On the other direction, profitability, growth opportunities and firm size seems to be positively correlated with the presence of firm in the ISE index. 
Table 4 - Correlation Matrix for Model Variables

\begin{tabular}{|c|c|c|c|c|c|c|c|c|c|}
\hline & ISE & HI5 & OWC1 & OWC2 & OWC3 & OWC4 & OWC5 & ROA & GROP \\
\hline ISE & 1 & & & & & & & & \\
\hline HI5 & $\begin{array}{r}-0,059 \\
(0,016)\end{array}$ & 1 & & & & & & & \\
\hline OWC1 & $\begin{array}{r}-0,052 \\
(0,033)\end{array}$ & $\begin{array}{r}0,973 \\
(0,000)\end{array}$ & 1 & & & & & & \\
\hline OWC2 & $\begin{array}{r}-0,028 \\
(0,249)\end{array}$ & $\begin{array}{r}0,895 \\
(0,000)\end{array}$ & $\begin{array}{r}0,911 \\
(0,000)\end{array}$ & 1 & & & & & \\
\hline OWC3 & $\begin{array}{r}-0,036 \\
(0,140)\end{array}$ & $\begin{array}{r}0,834 \\
(0,000)\end{array}$ & $\begin{array}{r}0,840 \\
(0,000)\end{array}$ & $\begin{array}{r}0,973 \\
(0,000)\end{array}$ & 1 & & & & \\
\hline OWC4 & $\begin{array}{r}-0,040 \\
(0,107)\end{array}$ & $\begin{array}{r}0,788 \\
(0,000)\end{array}$ & $\begin{array}{r}0,782 \\
(0,000)\end{array}$ & $\begin{array}{r}0,931 \\
(0,000)\end{array}$ & $\begin{array}{r}0,985 \\
(0,000)\end{array}$ & 1 & & & \\
\hline OWC5 & $\begin{array}{r}-0,045 \\
(0,071)\end{array}$ & $\begin{array}{r}0,755 \\
(0,000)\end{array}$ & $\begin{array}{r}0,742 \\
(0,000)\end{array}$ & $\begin{array}{r}0,896 \\
(0,000)\end{array}$ & $\begin{array}{r}0,962 \\
(0,000)\end{array}$ & $\begin{array}{r}0,992 \\
(0,000)\end{array}$ & 1 & & \\
\hline ROA & $\begin{array}{r}0,129 \\
(0,000)\end{array}$ & $\begin{array}{r}-0,069 \\
(0,005)\end{array}$ & $\begin{array}{r}-0,065 \\
(0,009)\end{array}$ & $\begin{array}{r}-0,064 \\
(0,010)\end{array}$ & $\begin{array}{r}-0,068 \\
(0,006)\end{array}$ & $\begin{array}{r}-0,069 \\
(0,005)\end{array}$ & $\begin{array}{r}-0,072 \\
(0,003)\end{array}$ & 1 & \\
\hline GROP & $\begin{array}{r}0,089 \\
(0,000)\end{array}$ & $\begin{array}{r}-0,154 \\
(0,000)\end{array}$ & $\begin{array}{r}-0,142 \\
(0,000)\end{array}$ & $\begin{array}{r}-0,158 \\
(0,000)\end{array}$ & $\begin{array}{r}-0,174 \\
(0,000)\end{array}$ & $\begin{array}{r}-0,180 \\
(0,000)\end{array}$ & $\begin{array}{r}-0,188 \\
(0,000)\end{array}$ & $\begin{array}{r}0,389 \\
(0,000)\end{array}$ & 1 \\
\hline SIZE & $\begin{array}{r}0,408 \\
(0,000)\end{array}$ & $\begin{array}{r}0,015 \\
(0,554)\end{array}$ & $\begin{array}{r}0,036 \\
(0,144)\end{array}$ & $\begin{array}{r}0,038 \\
(0,121)\end{array}$ & $\begin{array}{r}0,010 \\
(0,676)\end{array}$ & $\begin{array}{r}-0,015 \\
(0,538)\end{array}$ & $\begin{array}{r}-0,027 \\
(0,266)\end{array}$ & $\begin{array}{r}0,111 \\
(0,000)\end{array}$ & $\begin{array}{r}-0,088 \\
(0,000)\end{array}$ \\
\hline
\end{tabular}

Notes:

HI5 is the Herfindahl index for voting ownership concentration in hands of the five main shareholders. OWC ( 1 to 5 ) refers to the sum of voting shares (\%) in hands of the main, the two main, and so forth, until the five main shareholders. ROA is return on assets. GROP stands for growth opportunities, proxied by Tobin's Q. SIZE proxies for firm size, being calculated as Ln of total assets. Correlation coefficients and p-values (in parentheses) exhibited.

Our main results can be depicted from logit model estimates that have the pertinence to the ISE index as the dependent variable. As hypothesized, voting ownership concentration has shown to affect negatively firm Corporate Social Responsibility (CSR), as proxied by the probability of a firm being in the ISE index (Table 5). This result is consistent with models estimated with different measures of ownership concentration, the sum of voting stocks in hands of the five main shareholders (OWC1, OWC2, OWC3, OWC4, OWC5), and also by the Herfindahl index among the five main stockholders (HI5). Such result is consistent with the argument that large controlling shareholders may not see social policy, including social and environmental concerns, as relevant. 
Table 5 - Logit Regression for the Whole Sample

\begin{tabular}{|c|c|c|c|c|c|c|}
\hline & (i) & (ii) & (iii) & (iv) & (v) & (vi) \\
\hline HI5 & $-1.5612^{* * *}$ & & & & & \\
\hline OWC1 & & $-1.9465^{* * *}$ & & & & \\
\hline OWC2 & & & $-2.0006^{* * *}$ & & & \\
\hline OWC3 & & & & $-1.9508^{* * *}$ & & \\
\hline OWC4 & & & & & $-1.8085^{* * *}$ & \\
\hline OWC5 & & & & & & $-1.7601^{* * * *}$ \\
\hline ROA & $2.2299^{*}$ & $2.2464^{*}$ & $2.4093^{* *}$ & $2.3385^{*}$ & $2.3054^{*}$ & $2.2633^{*}$ \\
\hline GROP & $0.5666^{* * *}$ & $0.5730^{* * *}$ & $0.5582^{* * *}$ & $0.5613^{* * *}$ & $0.5657^{\text {**** }}$ & $0.5667^{* * *}$ \\
\hline SIZE & $1.1897^{* * *}$ & $1.2016^{* * *}$ & $1.2038^{* * *}$ & $1.1960^{* * *}$ & $1.1937^{* * *}$ & $1.1945^{* * *}$ \\
\hline sd1 & $-2.6900^{* * * *}$ & $-2.4506^{* * *}$ & $-2.6606^{* * *}$ & $-2.7662^{* * *}$ & $-2.8348^{* * *}$ & $-2.8882^{* * *}$ \\
\hline $\mathrm{sd} 2$ & $1.3868^{* * *}$ & $1.5088^{* * *}$ & $1.5342^{* * * *}$ & $1.4848^{* * *}$ & $1.4143^{\text {*** }}$ & $1.3697^{* * *}$ \\
\hline $\mathrm{sd} 3$ & $1.9906^{* * *}$ & $2.0631^{* * *}$ & $2.1049^{* * *}$ & $2.0530^{* * *}$ & $2.0336^{\text {**** }}$ & $2.0283^{* * *}$ \\
\hline sd4 & 0.6260 & 0.6442 & 0.5928 & 0.5490 & 0.5501 & 0.5312 \\
\hline $\operatorname{sd} 5$ & 0.6152 & 0.7512 & 0.7440 & 0.6981 & 0.6288 & 0.5798 \\
\hline sd6 & 0.2827 & 0.3394 & 0.4477 & 0.4047 & 0.3795 & 0.3618 \\
\hline $\operatorname{sd} 8$ & 0.3263 & 0.4551 & 0.4688 & 0.3669 & 0.2648 & 0.1992 \\
\hline sd9 & $2.6922^{* * *}$ & $2.8507^{* * *}$ & $2.9234^{* * *}$ & $2.8105^{* * *}$ & $2.7056^{* * * *}$ & $2.6443^{* * *}$ \\
\hline $\operatorname{sd} 10$ & 0.1669 & 0.2496 & 0.2492 & 0.1501 & 0.0595 & 0.0007 \\
\hline Constant & $-20.9245^{* * *}$ & $-20.8175^{* * * *}$ & $-20.5610^{\text {**** }}$ & $-20.3113^{* * * *}$ & $-20.2689^{* * *}$ & $-20.2515^{* * *}$ \\
\hline $\mathrm{N}$ & 1649 & 1649 & 1649 & 1649 & 1649 & 1649 \\
\hline $\mathrm{R}^{2}$ & 0.4010 & 0.4052 & 0.4040 & 0.4015 & 0.3987 & 0.3977 \\
\hline LR $\operatorname{chi}^{2}(18)$ & 454.28 & 459.01 & 457.68 & 454.84 & 451.62 & 450.56 \\
\hline valor-p & 0.0000 & 0.0000 & 0.0000 & 0.0000 & 0.0000 & 0.0000 \\
\hline
\end{tabular}

Notes:

Dependent variable is the dummy ISE that signals the pertinence of firm i to the ISE index in year t. HI5 is the Herfindahl index for voting ownership concentration in hands of the five main shareholders. OWC (1 to 5) refers to the sum of voting shares (\%) in hands of the main, the two main, and so forth, until the five main shareholders. ROA is return on assets. GROP stands for growth opportunities, proxied by Tobin's Q. SIZE proxies for firm size, being calculated as Ln of total assets. Industry dummies exhibited: $\operatorname{sd} 1=$ Petroleum and fuel products; sd2 = Chemicals, Paper products, Metal-mechanical; sd $3=$ Equipment, Electrical machinery, and transport equipment; sd4 = Building and transportation; sd5 = Food products and beverages and tobacco; sd6 = Textile, clothing, leather and footwear; sd8 = Communication; sd9 = Electrical, Water supply and sanitary services; sd10 = Financial. ***,**, and * denote statistical significance of the coefficients at 1,5 , and $10 \%$ levels.

The negative effect of ownership concentration over corporate social responsibility found in this work is in line with previous works in Brazil (NUNES; TEIXEIRA et al., 2010; LOURENÇO; CASTELO BRANCO, 2013), and in distinct scenarios like Europe and China (LI; ZHANG, 2010; LÓPEZ-ITURRIAGA; LÓPEZ-DE-FORONDA, 2011). The explanation of such results is related to the fact that the reduced number of controlling shareholders, which is linked to high ownership concentration, has effects on agency relations. At the same that it contributes to the reduction of agency conflicts between managers and owners through better management monitoring and alleviating the free-rider problem, it may also favor the exacerbation of private benefits of control (DYCK; ZINGALES, 2004; RIYANTO; TOOLSEMA, 2008). Private benefits of control in excess may have a negative consequence on agency relations. Powerful controlling shareholders may be not so interested in improving 
firm relationship with a broad spectrum of stakeholders and with the environment, which might be costly. Such lack of interest may be detrimental to the improvement of corporate social responsibility and sustainability concerns. Indeed, large shareholders of Brazilian firms seem to have incentives to pursue private benefits of control, putting aside the interests of other stakeholders as proposed in other markets (LI; ZHANG, 2010; LÓPEZ-ITURRIAGA; LÓPEZ-DE-FORONDA, 2011). In the same vein, literature has also argued that dispersed ownership, which may lead to the presence of institutional and ethical investors, favors firms' concerns with a broader spectrum of stakeholders and social and sustainability, contrary to the situation of high concentrated ownership (SÁNCHEZ; SOTORRÍO; DÍEZ, 2011; LOURENÇO; CASTELO BRANCO, 2013).

Results in Table 6 refer to the alternate model of equation (1) that includes the lagged effect of the pertinence to the ISE index. Indeed, there seems to be persistence of Brazilian firms in composing the ISE index. The previous pertinence to the ISE index (ISE $\left.\mathrm{t}_{\mathrm{t}-1}\right)$ has a positive effect on the present situation (ISE). This is an indication that firms worry about keeping their CSR status, avoiding its decrease which would be a negative signal to society. This finding may be linked to firm reputation and legitimacy purposes. By disclosing social and sustainability actions the firm signals its concerns with CSR to the market and to an ample spectrum of stakeholders (DOWLING; PFEFFER, 1975; SUCHMAN, 1995; DEEGAN, 2002). Once starting such disclosure it seems to important to maintain the practice, otherwise it may be a negative signal with possible negative effect on the legitimacy process.

The adverse effect of ownership concentration has been confirmed in these alternate models. It is worth mentioning that growth opportunities (GROP) and firm size (SIZE) are positively correlated to the probability of the firm being present in the ISE index as hypothesized. 
Table 6 - Logit Regression for the Whole Sample

\begin{tabular}{|c|c|c|c|c|c|c|}
\hline & (i) & (ii) & (iii) & (iv) & (v) & (vi) \\
\hline $\mathrm{ISE}_{\mathrm{t}-1}$ & $4.2449^{* * *}$ & $4.2099^{* * * *}$ & $4.2106^{* * * *}$ & $4.2137^{* * * *}$ & $4.2293^{* * *}$ & $4.2384^{* * * *}$ \\
\hline HI5 & $-1.8680^{* * *}$ & & & & & \\
\hline OWC1 & & $-1.9296^{* * *}$ & & & & \\
\hline OWC2 & & & $-2.1295^{\text {*** }}$ & & & \\
\hline OWC3 & & & & $-2.2440^{* * *}$ & & \\
\hline OWC4 & & & & & $-2.3486^{* * *}$ & \\
\hline OWC5 & & & & & & $-2.4265^{\text {**** }}$ \\
\hline ROA & 0.5016 & 0.5995 & 0.6583 & 0.6262 & 0.6037 & 0.5209 \\
\hline GROP & $0.2796^{*}$ & $0.2862^{*}$ & $0.2826^{*}$ & $0.2880^{*}$ & $0.2947^{*}$ & $0.2989^{*}$ \\
\hline SIZE & $0.7502^{* * *}$ & $0.7653^{\text {*** }}$ & $0.7713^{* * *}$ & $0.7629^{* * *}$ & $0.7574^{* * *}$ & $0.7571^{\text {*** }}$ \\
\hline $\operatorname{sd} 1$ & -1.9920 & -1.8180 & -2.0066 & -2.0815 & -2.1342 & -2.1886 \\
\hline $\mathrm{sd} 2$ & 0.7939 & 0.8672 & 0.8969 & 0.8923 & 0.8680 & 0.8434 \\
\hline $\operatorname{sd} 3$ & 0.4496 & 0.5186 & 0.5183 & 0.5035 & 0.5181 & 0.5493 \\
\hline $\operatorname{sd} 4$ & -0.2894 & -0.3188 & -0.3798 & -0.4038 & -0.3931 & -0.4079 \\
\hline $\operatorname{sd} 5$ & 0.4513 & 0.5334 & 0.5314 & 0.5166 & 0.4641 & 0.4151 \\
\hline sd6 & -0.4239 & -0.4053 & -0.2668 & -0.2842 & -0.2869 & -0.2806 \\
\hline $\operatorname{sd} 8$ & 1.0645 & 1.0725 & 1.1527 & 1.1250 & 1.0934 & 1.0561 \\
\hline $\operatorname{sd} 9$ & $1.7866^{* * *}$ & $1.8325^{* * * *}$ & $1.9632^{* * * *}$ & $1.9220^{* * *}$ & $1.8908^{* * *}$ & $1.8611^{* * * *}$ \\
\hline $\operatorname{sd} 10$ & -0.0640 & -0.0884 & 0.0255 & -0.0057 & -0.0279 & -0.0542 \\
\hline Constant & $-14.3407^{* * *}$ & $-14.3141^{* * *}$ & $-14.0690^{* * * *}$ & $-13.7518^{* * *}$ & $-13.5367^{* * * *}$ & $-13.4356^{* * *}$ \\
\hline $\mathrm{N}$ & 1279 & 1279 & 1279 & 1279 & 1279 & 1279 \\
\hline $\mathrm{R}^{2}$ & 0.6286 & 0.6279 & 0.6285 & 0.6286 & 0.6288 & 0.6292 \\
\hline LR $\operatorname{chi}^{2}(18)$ & 591.29 & 590.61 & 591.23 & 591.35 & 591.47 & 591.86 \\
\hline valor-p & 0.0000 & 0.0000 & 0.0000 & 0.0000 & 0.0000 & 0.0000 \\
\hline
\end{tabular}

Notes:

Dependent variable is the dummy ISE that signals the pertinence of firm i to the ISE index in year t. HI5 is the Herfindahl index for voting ownership concentration in hands of the five main shareholders. OWC (1 to 5) refers to the sum of voting shares (\%) in hands of the main, the two main, and so forth, until the five main shareholders. ROA is return on assets. GROP stands for growth opportunities, proxied by Tobin's Q. SIZE proxies for firm size, being calculated as Ln of total assets. Industry dummies exhibited: sd1 = Petroleum and fuel products; sd2 = Chemicals, Paper products, Metal-mechanical; sd3 = Equipment, Electrical machinery, and transport equipment; sd4 = Building and transportation; sd5 = Food products and beverages and tobacco; sd6 = Textile, clothing, leather and footwear; sd8 = Communication; sd9 = Electrical, Water supply and sanitary services; sd10 = Financial. $* * *, * *$, and $*$ denote statistical significance of the coefficients at 1,5 , and $10 \%$ levels.

As theoretically expected, growth opportunities contribute positively for the firm pertinence to the ISE index. At the same time that a firm with growth opportunities needs to use all available funds to maximize such opportunities, this firm also needs to show that adopts high standards of social policy, signaling also sustainability concerns. This is important in the financial market. This finding of the positive influence of growth opportunities on CSR is in accordance with the proposal of hypothesis 3 and previous results in the international arena, and also in Brazil (ARTIACH; LEE et al., 2010; ZIEGLER; SCHRÖDER, 2010; LOURENÇO; CASTELO BRANCO, 2013).

It is also worth mentioning the positive effect of firm size on the probability of the firm being component of the ISE portfolio, as theoretically proposed in hypothesis 5, based on the 
argument that larger firms are more able to undertake social actions. This finding is also consistent with previous studies in different markets where, indeed, firm size favors Corporate Social Responsibility (ARTIACH; LEE et al., 2010; NUNES; TEIXEIRA et al., 2010; LOURENÇO; CASTELO BRANCO, 2013).

With regard to profitability, as predicted by hypothesis 4, a positive effect of profitability on CSR has been found in line with the virtuous cycle proposed by the Stakeholder Theory. Literature findings are not conclusive about the effect of profitability on CSR, with possible endogeneity being suggested (ARTIACH; LEE et al., 2010; ZIEGLER; SCHRÖDER, 2010; CRISÓSTOMO; FREIRE et al., 2011). The different measures for CSR may be one reason for the mixing results on the CSR-profitability sensitivity present in the literature (MARGOLIS; WALSH, 2001; 2003; ORLITZKY; SCHMIDT et al., 2003). In this work, the positive sensitivity found, which is in accordance with the slack resources theory, indicates that the higher profitability increases the probability of a firm composing the ISE index.

\section{CONCLUSIONS}

Literature has looked for determinants of Corporate Social Responsibility (CSR). Recently, research has given attention to the possible role played by ownership structure on firm social policy, due to reputational concerns, visibility, and the search for legitimizing firm actions.

This work examines whether ownership concentration and other factors moderate the level of Corporate Social Responsibility in Brazil, as proxied by firm membership to the ISE index. The findings show that CSR of Brazilian firms is adversely affected by ownership concentration. This result may be interpreted as an indication that controlling voting shareholders may not see social policy as a priority. Indeed, in the Brazilian context, powerful controlling shareholders seem to pursue private benefits of control, leaving aside the interests of other stakeholders that could benefit from firm social and sustainability concerns. This result is in line with argument that more dispersed ownership could capture the interests of investors with social concerns that has no power in high concentrated ownership.

Besides the adverse effect of ownership concentration on CSR, additional results are important to be highlighted. Previous membership to the ISE index has shown to increase the present probability of a firm being a member of the ISE index in the current year. That means that Brazilian firms try to maintain its CSR status, as considered by the membership to the ISE index. This is in accordance with the proposals that firms worry about legitimacy and 
reputational concerns. Once reaching a certain degree of social concerns and disclosure, firms try to maintain it. Leading CSR Brazilian firms are significantly larger, and face more growth opportunities. These two firm characteristics have shown to be able to increase CSR. Larger Brazilian firms actually worry more about social performance. Firms with good growth opportunities are more prone to look for CSR improvement. This may be, in fact, related to firm relation with funding market that appreciates high standards of firm social concerns.

We see some avenues of research following this work. The search for other measures for CSR is a constant challenge highlighted in the literature and deserves attention since the use of dummy variable is more limited than a detailed continuous measure. In this vein, it seems to be fruitful the use of other CSR. Additionally, we also envision the study of specific sectors as valuable.

Studying the effect of other ownership structure characteristics of Brazilian firms also emerges as another avenue for research. Future works could take into account, for example, insider ownership or the ownership of certain blockholders like institutional investors, government or other firms.

\section{ACKNOWLEDGMENTS}

The authors are grateful to the anonymous referees for their valuable suggestions on the review process. Vicente Lima Crisóstomo acknowledges support from CNPq (477343/2013-9 - Universal 14/2013).

\section{CONTRIBUTIONS OF AUTHORS}

Vicente Lima Crisóstomo contributed to the design of the work, estimating the models , analysis and interpretation of results, article writing and writing of the English text .

Maria Rafaela Oliveira contributed to the design work, data collection, analysis , interpretation of data, Article writing.

\section{REFERENCES}

AGUILERA, R. V. et al. Putting the $\mathrm{S}$ back in corporate social responsibility: a multilevel theory of social change in organizations. Academy of Management Review, v. 32, n. 3, p. 836-863, 2007.

AGUINIS, H.; GLAVAS, A. What we know and don't know about corporate social responsibility: a review and research agenda. Journal of Management, v. 38, n. 4, p. 932968, 2012.

ALLEN, J. W.; PHILLIPS, G. M. Corporate equity ownership, strategic alliances, and product market relationships. Journal of Finance, v. 55, n. 6, p. 2791-2815, 2000. 
ANDRADE, L. P. et al. Determinantes de adesão ao índice de sustentabilidade empresarial da bm\&fbovespa e sua relação com o valor da empresa. Revista Brasileira de Finanças, v. 11, n. 2, p. 181-213, 2013.

ARTIACH, T. et al. The determinants of corporate sustainability performance. Accounting and Finance, v. 50, n. 1, p. 31-51, 2010.

BARNEA, A.; RUBIN, A. Corporate social responsibility as a conflict between shareholders. Journal of Business Ethics, v. 97, n. 1, p. 71-86, 2010.

BARON, D. P.; HARJOTO, M. A.; JO, H. The economics and politics of corporate social performance. Business and Politics, v. 13, n. 2, p. 1-46, 2011.

BAUMANN-PAULY, D. et al. Organizing corporate social responsibility in small and large firms: size matters. Journal of Business Ethics, v. 115, n. 4, p. 693-705, 2013.

BITTENCOURT, E.; CARRIERE, A. Responsabilidade social: ideologia, poder e discurso na lógica empresarial. RAE-Revista de Administração de Empresas, v. 45, 2005. p. 10-22.

BM\&FBOVESPA. Índice de sustentabilidade empresarial - ISE. Bolsa de Valores de São Paulo, v. 2012, n. 10, nov. 2012.

CARROLL, A. B. A three-dimensional conceptual model of corporate performance. The Academy of Management Review, v. 4, n. 4, p. 497-505, 1979.

Corporate social responsibility: evolution of a definitional construct. Business $\boldsymbol{\&}$ Society, v. 38, n. 3, p. 268-295, 1999.

CHIH, H.-L.; CHIH, H.-H.; CHEN, T.-Y. On the determinants of corporate social responsibility: international evidence on the financial industry. Journal of Business Ethics, v. 93, n. 1, p. 115-135, 2010.

CLAESSENS, S.; YURTOGLU, B. B. Corporate governance in emerging markets: a survey. Emerging Markets Review, v. 15, p. 1-33, 2013.

CRISÓSTOMO, V. L. Inversión, Restricción Financiera y Estructura de Propiedad en Brasil. Saarbrücken: Editorial Académica Española (LAP LAMBERT Academic Publishing GmbH \& Co. KG), 2011.

CRISÓSTOMO, V. L.; FREIRE, F. S.; VASCONCELLOS, F. C. Corporate social responsibility, firm value and financial performance in Brazil. Social Responsibility Journal, v. 7, n. 2, p. 295-309, 2011.

CRISÓSTOMO, V. L.; LÓPEZ-ITURRIAGA, F. J.; VALLELADO, E. Nonfinancial companies as large shareholders alleviate financial constraints of Brazilian firm. Emerging Markets Review, v. 18, p. 62-77, 2014.

CROWTHER, D.; ARAS, G. Corporate social responsibility. David Crowther, Güler Aras \& Ventus Publishing ApS, 2008. 
CUERVO, Á. Corporate governance mechanisms: a plea for less code of good governance and more market control. Corporate Governance: An International Review, v. 10, n. 2, p. 84-93, 2002.

DAHLSRUD, A. How corporate social responsibility is defined: an analysis of 37 definitions. Corporate Social Responsibility and Environmental Management, v. 15, n. 1, p. 1-13, 2008.

DAM, L.; SCHOLTENS, B. Does ownership type matter for corporate social responsibility? Corporate Governance: An International Review, v. 20, n. 3, p. 233-252, 2012.

DEEGAN, C. The legitimising effect of social and environmental disclosures: a theoretical foundation. Accounting, Auditing \& Accountability Journal, v. 15, n. 3, p. 282-311, 2002.

DEEPHOUSE, D. L.; CARTER, S. M. An examination of differences between organizational legitimacy and organizational reputation. Journal of Management Studies, v. 42, n. 2, p. 329-360, 2005.

DOWLING, J. B.; PFEFFER, J. Organizational legitimacy: Social values and organizational behavior. Pacific Sociological Review, v. 18, n. 1, p. 122-136, 1975.

DYCK, A.; ZINGALES, L. Private benefits of control: an international comparison. The Journal of Finance, v. 59, n. 2, p. 537-600, 2004.

ENG, L. L.; MAK, Y. T. Corporate governance and voluntary disclosure. Journal of Accounting and Public Policy, v. 22, p. 325-345, 2003.

FREEMAN, R. E.; PHILLIPS, R. A. Stakeholder theory: a libertarian defense. Business Ethics Quarterly, v. 12, n. 3, p. 331-349, 2002.

FREEMAN, R. E.; WICKS, A. C.; PARMAR, B. Stakeholder theory and "the corporate objective revisited”. Organization Science, v. 15, n. 3, p. 364-369, 2004.

GARRIGA, E.; MELÉ, D. Corporate social responsibility theories: mapping the territory. Journal of Business Ethics, v. 53, n. 1-2, p. 51-71, 2004.

GODOS-DÍEZ, J. L.; FERNÁNDEZ-GAGO, R.; CABEZA-GARCÍA, L. Propiedad y control en la puesta en práctica de la RSC. Cuadernos de economía y dirección de la empresa, v. 15, n. 1, p. 1-11, 2012.

GOERGEN, M.; RENNEBOOG, L. Investment policy, internal financing and ownership concentration in the UK. Journal of Corporate Finance, v. 7, n. 3, p. 257-284, sep. 2001.

GRIFFIN, J. J.; MAHON, J. F. The corporate social performance and corporate financial performance debate: Twenty-five years of incomparable research. Business and Society Review, v. 36, n. 1, p. 5-31, 1997.

HARJOTO, M. A.; JO, H. Corporate social responsibility and operating performance. Journal of the Academy of Business and Economics, v. 8, n. 1, p. 59-71, 2008. 
HODGSON, A.; LHAOPADCHAN, S.; BUAKES, S. How informative is the Thai corporate governance index? A financial approach. International Journal of Accounting and Information Management, v. 19, n. 1, p. 53 -79, 2011.

HUSTED, B.; SALAZAR, J. J. Taking Friedman seriously: maximizing profits and social performance. Journal of Management Studies, v. 43, n. 1, p. 75-91, 2006.

JENSEN, M. C.; MECKLING, W. H. Theory of the firm: managerial behavior, agency cost and ownership structure. Journal of Financial Economics, v. 3, n. 4, p. 305-360, 1976.

JOHNSON, R. A.; GREENING, D. W. The effects of corporate governance and institutional ownership types on corporate social performance. Academy of Management Journal, v. 42, n. 5, p. 564-576, 1999.

LA PORTA, R. et al. Law and finance. Journal of Political Economy, v. 106, n. 6, p. 1113$1155,1998$.

LERNER, L. D.; FRYXELL, G. E. An empirical study of the predictors of corporate social performance: a multi-dimensional analysis. Journal of Business Ethics, v. 7, n. 12, p. 951958, 1988.

LI, W.; ZHANG, R. Corporate social responsibility, ownership structure, and political interference: evidence from China. Journal of Business Ethics, v. 96, p. 631-645, 2010.

LI, W. A.; TANG, Y. An evaluation of corporate governance evaluation, governance index (CGI) and performance: evidence from Chinese listed companies in 2003. Frontiers of Business Research in China, v. 1, n. 1, p. 1-18, 2007.

LÓPEZ-ITURRIAGA, F. J.; CRISÓSTOMO, V. L. Do leverage, dividend payout and ownership concentration influence firms' value creation? An analysis of Brazilian firms. Emerging Markets Finance and Trade, v. 46, n. 3, p. 80-94, 2010.

LÓPEZ-ITURRIAGA, F. J.; LÓPEZ-DE-FORONDA, Ó. Corporate social responsibility and large shareholders: an analysis of european multinational enterprises. Transnational Corporations Review, v. 3, n. 3, p. 17-33, 2011.

LÓPEZ, M. V.; GARCIA, A.; RODRIGUES, L. Sustainable development and corporate performance: a study based on the dow jones sustainability index. Journal of Business Ethics, v. 75, p. 285-300, 2007.

LOURENÇO, I. C.; CASTELO BRANCO, M. Determinants of corporate sustainability performance in emerging markets: the Brazilian case. Journal of Cleaner Production, v. 57, n. 15 , p. 134-141, 2013.

MARCONDES, A. W.; BACARJI, C. D. ISE: sustentabilidade no mercado de capitais. São Paulo: Report Editora LTDA, 2010.

MARGOLIS, J. D.; WALSH, J. P. People and profits?: The search for a link between a company's social and financial performance. Mahwah, NJ: Lawrence Erlbaum Associates, Inc, 2001. 
Misery loves companies: rethinking social initiatives by business. Administrative Science Quarterly, v. 48, n. 2, p. 268-305, 2003.

MAURY, B.; PAJUSTE, A. Multiple large shareholders and firm value. Journal of Banking \& Finance, v. 29, n. 7, p. 1813-1834, 2005.

NUNES, J. G. et al. Análise das variáveis que influenciam a adesão das empresas ao Índice BM\&F Bovespa de Sustentabilidade Empresarial BASE - Revista de Administração e Contabilidade da Unisinos, v. 7, n. 4, p. 328-340, 2010.

ORLITZKY, M. Does firm size confound the relationship between corporate social performance and firm financial performance? Journal of Business Ethics, v. 33, p. 167-180, 2001.

ORLITZKY, M.; SCHMIDT, F. L.; RYNES, S. L. Corporate social and financial performance: a meta-analysis. Organization Studies, v. 24, n. 3, p. 403-441, 2003.

RIYANTO, Y. E.; TOOLSEMA, L. A. Tunneling and propping: a justification for pyramidal ownership. Journal of Banking \& Finance, v. 32, n. 10, p. 2178-2187, 2008.

ROBERTSON, D. C. Corporate social responsibility and different stages of economic development: Singapore, Turkey, and Ethiopia. Journal of Business Ethics, v. 88, p. 617633, 2009.

SAID, R.; ZAINUDDIN, Y. H.; HARON, H. The relationship between corporate social responsibility disclosure and corporate governance characteristics in Malaysian public listed companies. Social Responsibility Journal, v. 5, n. 2, p. 212-226, 2009.

SÁNCHEZ, J. L. F.; SOTORRÍO, L. L.; DÍEZ, E. B. The relationship between corporate governance and corporate social behavior: a structural equation model analysis. Corporate Social Responsibility and Environmental Management, v. 18, n. 2, p. 91-101, 2011.

SCHIANTARELLI, F.; SEMBENELLI, A. Form of ownership and financial constraints: Panel data evidence from flow of funds and investment equations. Empirica, v. 27, n. 2, p. 175-192, 2000.

SHRIVASTAVA, P. Ecocentric management for a risk strategy. Academy of Management Review, v. 20, n. 1, p. 118-137, 1995.

SILVEIRA, A. D. M. et al. Endogeneity of Brazilian corporate governance quality determinants. Corporate Governance, v. 10, n. 2, p. 191 - 202, 2010.

SKILLIUS, A.; WENNBERG, U. Continuity, credibility and comparability: key challenges for corporate environmental performance measurement and communication. Lund University. 1998

STATMAN, M. Socially responsible indexes. Journal of Portfolio Management, v. 3, p. 100-109, 2006.

SUCHMAN, M. C. Managing legitimacy: strategic and institutional approaches. The Academy of Management Review, v. 20, n. 3, p. 571-610, 1995. 
TILLING, M. V.; TILT, C. A. The edge of legitimacy: voluntary social and environmental reporting in Rothmans' 1956-1999 annual reports. Accounting, Auditing \& Accountability Journal, v. 23, p. 55-81, 2010.

UDAYASANKAR, K. Corporate social responsibility and firm size. Journal of Business Ethics, v. 83, p. 167-175, 2008.

ULLMAN, A. A. Data in search of a theory: a critical examination of the relationships among social performance, social disclosure, and economic performance of US firms. Academy of Management Review, v. 10, n. 3, p. 540-557, 1985.

VILLALONGA, B.; AMIT, R. How do family ownership, control and management affect firm value? Journal of Financial Economics, v. 80, n. 2, p. 385-417, 2006.

WADDOCK, S. Creating corporate accountability: foundational principles to make corporate citizenship real. Journal of Business Ethics, v. 50, n. 4, p. 313-327, 2004.

WADDOCK, S. A.; GRAVES, S. B. The corporate social performance-financial performance link. Strategic Management Journal, v. 18, n. 4, p. 303-319, 1997.

ZIEGLER, A.; SCHRÖDER, M. What determines the inclusion in a sustainability stock index? A panel data analysis for European firms. Ecological Economics, v. 69, n. 4, p. 848$856,2010$. 